\title{
The Supreme Court Decision on Obama Care Part 1
}

\author{
Gilbert Berdine, MD
}

The starting point for understanding the Court's decision is an understanding of the bases for the original lawsuit. The Court began its opinion by stating these bases.

In 2010, Congress enacted the Patient Protection and Affordable Care Act in order to increase the number of Americans covered by health insurance and decrease the cost of health care. One key provision is the individual mandate, which requires most Americans to maintain "minimum essential" health insurance coverage. ${ }^{[(1) \text { p. 1] }}$

Another key provision of the Act is the Medicaid expansion. The current Medicaid program offers federal funding to States to assist pregnant women, children, needy families, the blind, the elderly, and the disabled in obtaining medical care. 42 U. S. C. $\$ 1396 d(a)$. The Affordable Care Act expands the scope of the Medicaid program and increases the number of individuals the States must cover. ${ }^{[(1) \text { p. 1] }}$

Twenty-six States, several individuals, and the National Federation of Independent Business brought suit in Federal District Court, challenging the constitutionality of the individual mandate and the Medicaid expansion. ${ }^{[(1)}$ p.2]

In order to understand the impact of the Court's decision on US health care, we must first examine the rationales for the individual mandate and Medicaid expansion, then we must examine what the Court affirmed and what the Court struck down from the Patient Protection and Affordable Care Act. As stated by the Court, Congress intended for more people to be covered by health insurance. There are two groups of people not covered by health insurance: those who want insurance but cannot afford it, and those who do not want health insurance. Those who cannot afford in

Corresponding author: Gilbert Berdine MD Contact Information: Gilbert. Berdine@ttuhsc.edu DOI: 10.12746/swrccc2013.0101.007 surance are further divided: those with ordinary health risks and are too poor to afford ordinary health insurance, and those who have extraordinary health risks which prices their insurance beyond ordinary means. The ACA recognizes these differences and by design has very different impacts on these groups of people.

One intended effect of the ACA was to protect people with pre-existing conditions from losing their insurability. Diabetes can be used to illustrate the actuarial effects of pre-existing conditions. The US Department of Health and Human Services (HHS) estimates that 2002 per capita health expenditures were $\$ 13,242$ for those with diabetes and $\$ 2,560$ for those without diabetes (2). A new health insurance policy based on sound actuarial principles for a diabetic would require a premium exceeding $\$ 13,242$ per year, while others would pay some figure above $\$ 2,560$. Such a policy would be beyond the means of most people with diabetes. The diabetic becomes uninsurable. If the government requires the pool to be homogenized so as to ignore diabetes, then the premium for diabetics would be less and the premium for everyone else would be more. There are important effects on incentives of such a homogenized risk pool. Those without diabetes have no incentive to insure themselves against developing diabetes until after the condition has occurred. Those without diabetes will choose not to purchase insurance unless their lack of diabetes is reflected by a lower premium commensurate with their lower risk. Those without diabetes will participate in a homogenized pool only if they are compelled to do so. Hence, the individual mandate to purchase insurance is made necessary by a homogenized risk pool without pre-existing conditions.

The expansion of Medicaid was the mechanism chosen for insuring those who desire ordinary insurance but are too poor to purchase it. As noted by the Court, ACA requires that States increase coverage for Medicaid to include "adults with incomes up to 133 percent of the federal poverty level, whereas 
many States now cover adults with children only if their income is considerably lower, and do not cover childless adults at all." [(1) p. 2] Had Congress fully funded the Medicaid expansion, there would have been no reason for a penalty against non-participation. "Section 1396c gives the Secretary of Health and Human Services the authority to penalize States that choose not to participate in the Medicaid expansion by taking away their existing Medicaid funding." [(1) p. 5] The Court noted that Medicaid is routinely as much as $10 \%$ of a State's budget. "The threatened loss of over 10 percent of a State's overall budget is economic dragooning that leaves the States with no real option but to acquiesce in the Medicaid expansion.” [(1) p. 5]

The lawsuit challenged the constitutionality of the individual mandate and the coercive aspect of the Medicaid expansion. The ACA was affirmed in part and reversed in part. Different judges made up the majority for different aspects of the decision. Chief Justice Roberts positioned himself with each majority on each aspect of the Court's decision. A Court majority (Roberts, Ginsburg, Breyer, Kagan, and Sotomayer) affirmed the individual mandate as a Constitutional exercise of Congress's power under the Taxing and Spending Clause (Article I, Section 8, Clause 1). The Court ruled the individual mandate was a tax on people who choose not to purchase health insurance. This was the main part of the opinion.

Scalia, Thomas, Kennedy, and Alito wrote a Dissent and wanted to reverse the entire ACA. The Dissent argued that the individual mandate was a penalty rather than a tax and that the Constitution contains no provision for penalties against behaviors people choose not to engage in. Roberts joined them to form a 5-4 majority on a narrow Constitutional interpretation of the justification of ACA. They agreed that the individual mandate was not permitted by either the Commerce Clause (Article I, Section 8, Clause 3) or the Necessary and Proper Clause (Article I, Section 8, Clause 18). This was a narrow interpretation in that this decision did not strike down the individual mandate. Rather, this narrow interpretation serves as precedent for future cases involving the scope of the Commerce clause and the Necessary and Proper Clause.
Breyer and Kagan joined Roberts, Scalia, Thomas, Kennedy and Alito to strike down the coercive aspect of the Medicaid expansion by a 7-2 majority. This was the portion of ACA reversed by the Court's decision. It is notable, therefore, that the two actions of the Court were supported by different factions. Chief Justice Roberts, Breyer and Kagan were an unlikely alliance forming the core of the two different Court Majorities belonging to both parts of the decision.

All nine judges agreed that the lawsuit was not barred by the Tax Anti-Injunction Act (U.S. Federal Statute) by being a tax. This was a technical decision that has little impact on policy, law, or future Court decisions.

Ginsburg and Sotomayer wrote a Dissent arguing that the Medicaid expansion with the penalty for nonparticipation was permitted by the Spending clause. They were joined in Dissent by Breyer and Kagan arguing that the individual mandate was permitted by the Commerce clause.

As far as the health care industry is concerned, leaving aside debates over the judicial and constitutional arguments made by the various factions within the Court, the ACA with the individual mandate stands, but the States are free to reject the Medicaid expansion without penalty.

The above discussion is a simple statement of facts that are easily confirmed from the public record. Part 2 will examine the effects of the Supreme Court decision on health care from the perspective of Austrian economics.

KEY WORDS : Health Care Reform, Politics, Supreme Court Decisions

Author Affiliation: Dr. Berdine is a pulmonary physician in the Department of Internal Medicine TTUHSC.

Received: $10 / 18 / 2012$

Accepted: $12 / 7 / 2012$

Reviewers: William Webster, JD; Clarke Cochran, PhD

Published electronically: 1/2/2013

Conflict of Interest Disclosures: None 


\section{REFERENCES}

1. http://www.supremecourt.gov/opinions/11pdf/11393c3a2.pdf

2. http://www.foh.dhhs.gov/NYCU/diabetescost.asp 